\title{
PEWARISAN NILAI SEBAGAI PEMBENTUK KEPRIBADIAN BERKARAKTER MELALUI FALSAFAH HUMA BETANG SUKU DAYAK KALIMANTAN
}

\author{
Anggia Amanda Lukman \\ SMA 1 Parung Kuda, Sukabumi \\ Email: anggiaamanda@student.upi.edu
}

\begin{abstract}
Abstrak Makna nilai dalam senuah kearifan kola menyiratkan kebiasaan yang terjadi dalam sebuah masyarakat terutama masyarakat adat salah satunya filosofi huma bentang yang mencerminkan nilai kebiijakan dan keserhanaan di dareah kalimantan terutama daerah pinggir sungai hingga hulu. Filosofi huma bentang menjelaskan sikap toleransi dan unsur pemimpinan dalam kehidupan dalam perbedaan karena didalam huma bentang terdapat beberpa keluarga yang hidup bersama. Metode penelitian yang digunakan yakni penelitian literatur yakni metode pengumpulan data yang digunakan dalam penelitian sosial untuk menelusuri data historiesdengan sumber literatur primer yang ditulis oleh peneliti lain secara langsung dari pengalaman. Pemaknaan kembali pewarisan nilai-nilai merupakan jalan yang tepat untuk melawan pengaruh negatif globalisasi dan modernisasi, serta sebagai program pembentukan kepribadian generasi muda dengan mensosialisasikan kearifan lokal melalui pendidikan terhadap generasi muda penerus bangsa.
\end{abstract}

Kata kunci: $\quad$ Nilai, Kepribadian, Berkarakter dan Huma Betang

\section{PENDAHULUAN}

Indonesia merupakan negara kepulauan yang sangat luas terdiri dari pulau Jawa, Sumatera, Kalimantan, Sulawesi, Papua hingga pulau-pulau kecil yang tersebar di perairan NKRI. Letak goegrafis yang saling berjauhan menjadi faktor pendorong utama dalam keanekaragaman kebudayaan antara satu pulau dengan pulau lain dan menghasilkan kebiasaan masyarakat yang berbeda disesuaikan dengan kondisi lingkungan serta iklim dalam pembentukan karakter budaya sebagai kearifan lokal (Koentjaraningrat, 1984). Dalam menjaga dan melestarikan kebudayaan sendiri, secara proses mantransfernya yang paling efektif dengan cara pendidikan baik secara formal maupun nonformal (Agung Hartoyo 2012). Manusia sebagai mahluk berakal dan berbudaya selalu berupaya untuk mengadakan perubahanperubahan. Dengan sifatnya yang kreatif dan dinamis manusia terus berevolusi meningkatkan kualitas hidup yang semakin terus maju namun tak perlu meninggalkan apa yang sudah menjadi warisan.

Makna nilai dari sebuah kearifan mencerminkan kebiasaan masyarakat adat dalam menjalankan kehidupan yang bijaksana, salah satunya tercermin pada kearifan lokal Huma Betang Suku Dayak Kalimantan. "Huma Betang" adalah dalam istilah sehari-hari "rumah besar" yang dihuni banyak orang dengan beragam agama dan kepercayaan tetapi tetap rukun serta damai (Usop et al. 2011). Huma Betang ini merupakan rumah tradisional suku dayak kalimantan ,terutama di daerah hulu sungai yang biasanya menjadi pusat pemukiman suku Dayak dan menjadi jalur transportasi untuk melakukan berbagai mobilitas. Huma bentang atau rumah panjang memiliki makna yang luar biasa dimana makna dari pembuatan hingga hasil pembangunan mencerminkan toleransi dan kepemimpinan (Neni et al. 2012). Rumah betang menjadi sentral segala aktivitas masyarakat suku dayak yang para penghuni rumah bentang di atur berdasarkan aturan adat yang telah di sepakati.

Maka upaya pengaplikasian kebudayaan yang menghasilkan pengetahuan adat berupa kearifan lokal sangat baik jika dilakukan melalu pendidikan baik formal seperti sekolah maupun non formal seperti lembaga keluarga dan masyarakat, selain sebagai lembaga pengembangan kemampuan kognitif untuk 
mempersiapkan mereka hidup di masyarakat secara luas. Sosialisasi melalui pendidikan merupakan tempat dalam mewariskan nilai kearifan budaya sebagai identitas masyarakatnya di mata dunia. Kearifan budaya ini akan menjadikan anak bangsa memiliki rasa nasionalisme terhadap negaranya serta kesopanan yang mewakili sebuah bangsa yang menjungjung tinggi nilai kearifan (Fajarini n.d.). Keduanya memiliki hubungan yang sangat dan saling melengkapi satu sama lain. Pewarisan makna nilai untuk pembentukan kepribadian yang baik cenderung berasal dari kebudaayan masyarakt tersebut, makna yang terkandung dalam kebudayaan sering disebut sebagai kearifan lokal. Hal tersebutlah yang melatarbelakangi penulisan penelitian ini. Tujuan penelitian ingin menggali filosfi yang mengandung banyak nilai baik sebagai pedoman kehidupan dan sebagai pembentuk kepribadian.

\section{TINJAUAN PUSTAKA}

Kearifan lokal dari dua kata yaitu kearifan (wisdom), dan lokal (local). Secara umum maka local wisdom (kearifan setempat) dapat dipahami sebagai gagasan-gagasan setempat (local) yang bersifat bijaksana (Alam 2012). Kearifan lokal merupakan pengetahuan atau pandangan hidup masyarakat setempat yang memiliki hubungan dengan pemenuhan kebutuhan hidup baik secara materi maupun sosial dimana kearifan lokal ini menjadi titik penghubungan dari generasi satu ke generasi berikut karena kearifan lokal merupakan konsep, ide dan gagasan yang senantiasa di transisikan keapda generasi berikut sehingga terbangun suatu keserasian dalam menata hidup dan lingkungan (Wahyudi, Agung 2014).

Pembelajaran berdasarkan budaya terdapat empat bentuk (Irianto 2016), yaitu: a) Belajar tentang budaya, yaitu menempatkan budaya sebagai bidang ilmu yang dipelajari dalam program belajar berupa mata pelajarn. B) Belajar dengan budaya maksudnya proses pembelajaran terjadi pada saat budaya diperkenalkan kepada peserta didik sebagai metode pembelajaran. C) Belajar melalui budaya, merupakan salah satu strategi yang memberikan kesempatan kepada peserta didik untuk mencapai pemahaman dalam suatu mata pelajaran melalui ragam perwujudan budaya. D) Belajar berbudaya artinya bentuk pembelajaran yang menjadikan budaya sebagai patokan dan pedoman bertindak.

Pengertian dari dayak dalam bahasa setempat berarti orang yang tinggal di hulu sungai, hal ini berdasarkan pada tempat tinggal mereka yang berada di hulu sungai-sungai besar. Keunikan ini menjadi perbedaan suku dayak dengan kebudayaan Indonesia lainnya yang pada umumnya bermula di daerah pantai. Masyarakat suku Dayak menjalani sebagian besar hidupnya di sekitar daerah aliran sungai pedalaman Kalimantan (Usop et al. 2011). Sebagian besar orang kalimantan yang memeluk agama Islam disebut sebagai orang Melayu atau orang Banjar, sedangkan orang kalimantan yang menolak agama Islam kembali menyusuri sungai masuk ke pedalaman di Kalimantan dan merekalah suku asli dayak.

Rumah Betang atau di kenal dengan rumah panjang merupakan rumah tradisional suku dayak dan terdapat di berbagai penjuru pulau kalimantan serta menjadi pusat kegiatan masyarakat suku dayak. Rumah bentang biasanya berukuran panjang sekita 150 meter dan lebar hingga 30 meter, umumnya rumah Betang dibangun dalam bentuk panggung dengan ketinggian tiga hingga lima meter dari tanah (Neni et al. 2012). Tujuan mengapa rumah bentang dibangun dengan tinggi sekitar 3 sampai 5 meter untuk menghindari datangnya banjir pada musim penghujan yang mengancam daerah-daerah di hulu sungai di Kalimantan. Dalam satu desa bisa terdapat lebih dari satu rumah bentang atau rumah panjang, bianya di huni oleh beberapa kepala keluarga yang tinggal dengan di batasi sekat-sekat.

Makna huma betang atau rumah panjang menyiratkan mengenai kebersamaan suku daya yang tinggal di atap yang sama dan menjalankan kehidupan sehari-hari secara bersamaan. Di dalam rumah betang, penghuninya diatur berdasarkan hukum adat yang telah disepakati bersama sebagi pedoman hidup. Maka nilai menjadi keunikan dalam makna huma betang ini ialah kebersamaan ditengah perbedaan atara kelurga yang tinggal satu atap di huma betang (Fajarini n.d.).

\section{METODE}

Metode yang digunakan dalam penelitian ini ilah penelitian literatur sebagai cara memperoleh data penelitian untuk mengkaji dan menelusuri data historie (Sumarmo, Hidayat, and Zukarnaen 2011). Metode ini pun digunkan peneliti memalaui berbagai sumber baik artikel, penelitian, buku jurnal atau dokumen terkait filosofi huma betang. Adapun yang menjadi sumber yakni sember literatur primer sebagai cara memperoleh data data asli dari tulisan pnulis langsung. Dengan demikian informasi yang didapat dari studi kepustakaan ini dijadikan rujukan untuk memperkuat argumentasiargumentasi yang ada.

\section{PEMBAHASAN}


Filosofi Huma Betang di pulau Kalimantan memiliki makna yang sangat baik, dimana huma bentang mencerminkan kehidupan yang damai, toleransi dalam perbedaan. Dalam Huma Betang terdapat empat pilar falsafah hidup utama yaitu : Kejujuran, kesetaraan, kebersamaan dan taat aturan atau disebut dengan "Belom Bahadat" artinya hidup bertata krama dan "Belom Penyang Hinje Simpe" hidup dalam kesetaraan, kedamaian, toleransi, kebersamaan (Usop et al. 2011). Dari empat pilar tersebut muncul semangat persatuan yang menjunjung tinggi kebersamaan dalam menyikapi perbedaan secara jujur, sehingga tidak akan menjadi jurang yang memisahkan sekaligus menghancurkan. Dapat diambil kesimpulan melaui huma bentang ini sebagai pemaknaan dalam mempertahankan perbedaan di tengah kebersamaan sebagai bentuk proteksi dari pengaruh budaya asing.

Nilai pertama yakni kebersamaan yang tercermin dari rukunya para keluarga yang hidup dalam satu atap huma betang selain itu tercermin dari sikap kerjasama gotong royong. Kedua, kejujuran dimana terlihat dalam keseharian mereka saling menyapa dan ketika proses interaksi yang selalu disampaikan dengan jujur. Ketiga, kesetaraan adalah dimana sikap penghuni huma betang yang menganggap sama anggota kelurga lain yang tinggal di atap human betang tanpa melihar perbedaan latar belakang serta ciri fisik. Keempat, toleransi adalah sikap menghargai perbedaan atau pun latar belakang orang lain. Contoh dalam Huma Betang yang berbeda Agama satu sama lain.

Aturan "Belum Bahadat" tersebut berlaku bagi setiap masyarakat suku Dayak yang telah diterapkan sejak dini dan berlaku sertiap golongan masyarakat susku dayak hingga mereka dewasa bahkan setelah meninggal dunia. Peran adat istiadat dalam tata pergaulan hidup masyarakat antara lain (Agung Hartoyo 2012): a) Adat istiadat mengajarkan kepada anak-anak untuk menghormatii ayah/ibu, kakek/nenek, atau kepada paman dan bibi, dan anak muda wajib hormat kepada orang lain yang lebih tua. B) Adat istiadat mengajarkan bahwa antara kaum laki-laki dan kaum perempuan dalam suku dayak harus saling hormat menghormati satu sama lain, hal tersebut di buktikan dalam bahasa sangen "Tandak Batang Garing" yaitu : laki-laki disebut dengan "Habatang Garing, Habaner Garantung, Habasung Runjan" sedangkan perempuan disebut dengan "Balimut Bulau Pasihai Runjan". Artinya kaum laki-laki wajib menghormati, melindungi dan menjaga martabat kaum perempuan dan keluarganya. C) Adat istiadat mengajarkan untuk menghormati mereka yang telah menikah dan telah memiliki anak dengan cara memanggil mereka dengan menyebutkan nama anakanaknya.

Filosofi dari Huma Betang merupakan nilainilai yang selalu melekat pada diri setiap masyarakat kalimantan dalam arti kata nilai-nilai yang ada didalam Huma Betang tersebut bukan hanya sekedar warisan akan tetapi untuk dikelola oleh masyarakat Kalimantan (Usop et al. 2011). Walaupun tidak dapat dipungkiri lagi bahwa Huma Betang akan punah seiring berjalannya waktu dan arus globalisasi dan modernisasi jika masyarakat tidak berupaya melestarikannya.

Tidak dipungkiri arus globalisasi dan modernisasi seperti dua sisi uang logam yang mempunyai dampak positif maupun nagatif. Sebenarnya globalisasi itu sendiri memicu mayarakat menjadi lebih semangat untuk menjadi kreatif dan inovatif dalam berbagai hal akibat kesadaran mengenai persaingan global. Hal ini karena masyarakt sebagai Individu bebas menafsirkan nilai-nilai dan simbol budaya global sebagai akibat mudah dalam mengakses semua informasi yang ada dan berkembangnya nilai-nilai global seperti demokratisasi, transparansi, persamaan derajat, dan sebagainya (Yusriyauya 2013). Mudahnya mengakses berbagai macam informasi menimbulkan keanekaragaman perilaku yang sulit dibendung. Dengan demikian keadaan ini bisa mempengaruhi pembentukan pemikiran yang berlandasan budaya menjadi bertentangan dengan nilai-nilai budaya bangsa atau ideologi negara bahkan bisa merusak nilai-nilai moral bagi yang tidak siap menghadapinya (Property n.d.).

Revitalisasi sebagai wadah pengkembalian kembali mkan kearifan lokal yang semakin tergerus merupakan langkah yang paling efektif. Lanhgkah ini adalah langkah pelestarian kebudayaan yang di sisipkan dalam berbabagi cara diantaranya pendididikan sebagai program pendidikan berkarakter Upaya revitalisasi huma bentang ini dapat dilakukan melalui beberapa hal sebagai berikut:

Pertama melalui pendidikan informal dimana setiap masyarakat berusaha memperkokoh nilai dan norma yang berlaku pada para anggotanya dilakukan melalui proses sosialisasi. Peran pemangku tanggung jawab atas pewarisan nilai serta norma tersebut diberikan kepada orang tua sebagai wakil generasi sebelumnya kepada anakanaknya yang akan melanjutkan generasinya dan berlangsung dalam kehidupan keluarga.hal ini sama seperti makna rumah bentang, dimana rumah betang ini memperlihatkan kebersamaan artinya terdapat prose sosialisasi yang dilakukan oleh orang terdekat mengenagi budayanya atau kearifan lokalnya sebab keluarga merupakan lapangan pendidikan yang pertama, dan pendidiknya adalah kedua orang tua, orang tua adalah pendidik kodrati. Maka dari itu, keluarga 
merupakan basis dari bangsa, karena sangat menentukan keadaan bangsa itu sendiri melalui pengimplikasian makna yang terkandung dalam nilai-nilai Huma Bentang (syamsul Hadi 2010).

Kedua melalui Pendidikan formal yaitu lembaga sekolah dimana sejalan dengan fungsi dan peran pendidikan, maka sekolah sebagai pelanjut dari pendidikan keluarga. Sekolah pada hakikatnya tidak sekedar tempat transfer ilmu pengetahuan atau materi tertentu saja yang d UN, tetapi juga sebagai lembaga yang wajib menanamkan penegtahuan lokal sesuai budaya setempat. Dengan memberikan mata pelajaran berbasis karakter menyisipkan berbagai materi budaya lokal ke dalam materi pembelajaran. Seperti menyisipkan penegtahuan mengenai adat huma bentang selain sebagai media informasi dalam mengetahui seperti apa rumah bentang, juga sebagi materi yang menanamkan makna terpuji dari huma bentang. Kearifan lokal seperti nilai, norma, kebiasaan dalam huma bentang merupakan salah satu unsur penting yang harus ditanamkan sejak dini kepada generasi penerus guna memperkuat dan melestarikan adat budaya betang yaitu belum bahadat (hidup bertatakrama) (sutopo 2012).

Terakhir melalui pendidikan nonformal yaitu memunculkan atau mengperkuat kearifan loka melalui lingkungan masyarakat terhadap penanaman nilai-nilai estetika dan etika. Dalam artian yang lebih luas dapat diartikan bahwa pembentukan karakter seseorang tergantung dari pembentukan nilai-nilai, moral dan spiritual jika seseorang berada dalam lingkungan yang menjunjung tinggi nilai-nilai tersebut artinya penyimpangan terjadi akibat sub kebudayaan menyimpan. Fungsi dan peran masyarakat dalam pembentukan karakter akan sangat tergantung dari seberapa jauh masyarakat tersebut menjunjung norma nilai, moral dan spiritual itu sendiri (Kusumadara 2011).

\section{KESIMPULAN}

Huma bentang adalah rumah khas dari kalimantan khususnya suku dayak yang memiliki banyak keunikan selain dari bentuk dan ukurannya. Huma bentang memiliki filosofi nilai cerminan dari kehidupan masyarakatnya, seperti kebijaksanaan, kepemimpinan, kepatuhan, keberagaman dan kedamian atau toleransi antar anggota yang berbeda.nilai yang terdapat dalam filosifi huma bentang menjadi pedoman hidup masyarakat suku dayak dalam menjalankan kehidupannya. Maka, penting mengimplementasikan filosofi huma bentang dalam kehidupan yang lebih luas sebagai media pencegah hilangnya identitas generasi muda dalam era globalisasi dan modernisasi. Untuk itu, terdapat upaya penerapannya melalui pendidikan diharapkan mampu membentuk karakter pribadi penerus bangsa yang tidak goyah dan mudah rapuh oleh derasnya arus globalisasi dan modernisasi. Selain itu, perlu adanya aktualisasi nilai dalam kehidupan praktis yang sesuai dengan ideologi Pancasila, nilai-nilai yang terkandung dengan menjaga konsistensi, relevansi dan kontekstualisasinya .

\section{REFERENNSI}

Agung Hartoyo. 2012. "Eksplorasi Etnomatematika Pada Budaya Masyarakat Dayak Perbatasan Indonesia-Malaysia Kabupaten Sanggau Kalbar.” 13(1):14-23.

Alam, Dengan Lingkungan. 2012. "Kearifan Lokal Adat Masyarakat Sunda Dalam Hubungan Dengan Lingkungan Alam." 4(229):1-8.

Fajarini, Ulfah. N.D. "Peranan Kearifan Lokal Dalam Pendidikan Karakter."

Irianto, Agus Maladi. 2016. "Komodifikasi Budaya Di Era Ekonomi Global Terhadap Kearifan Lokal: Studi Kasus Eksistensi Industri Pariwisata Dan Kesenian Tradisional Di Jawa Tengah.” 27:213-36.

Koentjaraningrat, 1984. Kebudayaan Mentalitas Dan Pembangunan. Cetakan Ke-11. Jakarta.

Kusumadara, Afifah. 2011. "Pemeliharaan Dan Pelestarian Pengetahuan Tradisional Dan Ekspresi Budaya Tradisional Indonesia: Perlindungan Hak Kekayaan Intelektual Dan Non-Hak Kekayaan Intelektual.” 18(1):2041.

Moniaga, Sandra. 2002. "Hak-Hak Masyarakat Adat Dan Masalah Serta Kelestarian Lingkungan Hidup Di Indonesia 1.” (10):16.

Neni, Oleh, Puji Nur, Kabupaten Landak, And Kabupaten Sambas. 2012. "The Value Of Education In Paddy Cultivation Of Kanayatn Dayak In West." 15-25.

Property, Cultural. N.D. Adat And Indigeneity In Indonesia Universitätsverlag Göttingen.

Sumarmo, Utari, Wahyu Hidayat, And Rafiq Zukarnaen. 2011. "Kemampuan Dan Disposisi Berpikir Logis, Kritis, Dan Kreatif Matematik." 17-33.

Sutopo. 2012. "Artikel Kesehatan Kebudayaan Sebagai Pembentuk Identitas Nasional." Retrieved (Http://Takiyaazkah.Blogspot.Co.Id/2012/11 /Kebudayaan-Sebagai-PembentukIdentitas.Html).

Syamsul Hadi. 2010. "Todays Illuminator Hubungan Kebudayaan Dengan Pendidikan." Retrieved (Http://Hadirukiyah.Blogspot.Co.Id/2010/07 /Hubungan-Kebudayaan-DenganPendidikan.Html). 
Usop, Tari Budayanti Et Al. 2011. "Kearifan Lokal Dalam Arsitektur Kalimantan Tengah." 6:25-32.

Wahyudi, Agung. "Implementasi Sekolah Berbasis Kearifan Lokal Di Sd Negeri Sendangsari Pajangan". Skripsi. Fakultas Ilmu Pendidikan Universitas Negeri Yogyakarta. 2004.
Yusriyauya. 2013. "Pengaruh Perubahan Sosial Pada Pendidikan _ Yusriyauya." Retrieved (Https://Yusriyauya.Wordpress.Com/2013/0 1/17/Pengaruh-Perubahan-Sosial-PadaPendidikan/). 